\title{
The Modernization of the Armored Combat Vehicle Fleet of the Hungarian Defense Forces in Terms of Mobility \\ KOVÁCSHÁZY Miklós ${ }^{1}$
}

\begin{abstract}
The Hungarian Defence Forces (Magyar Honvédség) have several off-road com-bat vehicles of different ages and condition. One can find tracked-and wheeled equipment, such as battle tanks, armored infantry fighting vehicles, armored per- sonnel carriers, special purpose vehicles, and engineering machinery among them. Some of these devices are now obsolete, the exchange of the rest is becoming due. This study looks at the armored combat vehicle portfolio of the Hungarian Defence Forces, seeking an answer to the question what the role of the mobility of armed forces is; are only wheeled or tracked equipment needed, or both. I am going to re-view, on the basis of the main sources of literature, what results have been achieved in national military-technical life, in the field of mobility, by comparison and an examination of a selection of military use off-road vehicles.

Keywords: armored fighting vehicles, combat vehicle, armored infantry, off road mobility, cross country mobility, selection, comparison, exchange
\end{abstract}

\section{The modernization of the Hungarian Defense Forces, the condition of the armored fighting vehicle fleet}

With Hungary's NATO accession the Hungarian Defence Forces targeted the creation of a smaller but more efficient army which can facilitate the avoidance of armed conflicts, and which is able to protect the country and fulfill its international obligations independently or in alliance. As a result of the $23^{\text {rd }}$ July 1999 decree of the government, a strategic review of the Army has been completed. A development program started based on this, during which the flexible development of the existing assets was the essence of modernization. [1] Today, the Hungarian military armament, the vehicle fleet and the equipment need renewal again. [2] Development of the land forces almost completely stopped in the ' $80 \mathrm{~s}$. The maintenance activities, as well as industrial-maintenance background have narrowed down, depletion of reserves was forced, which together led to the stop of inefficient operating techniques. [1] It can be stated as a general characteristics that the military utility of means is low. A significant number of them are obsolete, maintenance becomes more difficult to ensure, their operation is so uneconomical. Therefore it means the replacement definitely needs to be solved. [3]

1 M.Sc. mechanical engineer, National University of Public Service, Doctoral School of Military Engineering, denkmeyer79@ gmail.com 
Table 1. Armored off-road devices of the Hungarian Defense Forces [4] [17]

\begin{tabular}{|l|c|c|c|c|c|c|c|c|}
\hline & Tank & \multicolumn{7}{|c|}{ Wheeled AVF } \\
\hline Type & T-72M1 & BTR-80 & $\begin{array}{c}\text { BTR- } \\
80 \mathrm{~A}\end{array}$ & $\begin{array}{c}\text { BRDM- } \\
1, \\
\text { BRDM- } \\
2\end{array}$ & Cougar & $\begin{array}{c}\text { HMMWV } \\
\text { M1151A1 }\end{array}$ & $\begin{array}{c}\text { MaxxPro } \\
\text { MRAP }\end{array}$ & $\begin{array}{c}\text { Rába } \\
\text { H14 }\end{array}$ \\
\hline $\begin{array}{l}\text { Amount } \\
\text { [pcs.] }\end{array}$ & $\begin{array}{c}15 \\
(43 \text { con- } \\
\text { served })\end{array}$ & $\begin{array}{c}413 \\
(100 \text { in } \\
\text { stock })\end{array}$ & 178 & 341 & 13 & 41 & 12 & 7 \\
\hline
\end{tabular}

The operating time of T-72 type tanks expired in 2010 although many are in fairly good technical condition. Their present amount — including preserved reserve — is not sufficient for the execution of combined arms training and for particular bond practice. As a result, the Army would find itself without the support of heavy weapons in case of traditional deploy- ment.

There is a somewhat more favorable picture of the armored fighting vehicles being inves- tigated. The wheeled combat vehicles BTR-80 and BTR-80A are of the appropriate standard but do not supply the long term armored fighting vehicle needs of the Hungarian Defence Forces. Between 2006 and 2010 a significant part of the fleet was modernized and rebuilt in order to support a variety of tasks. The BRDM vehicles according to their design can provide anti-armor and chemical protection functions. [5]

Because of the Hungarian participation in the mission in Afghanistan there was a need for armored vehicles that can provide appropriate fire support during patrol and transport duties. Therefore, the Hugarian Defense Forces started to use a small number of armored wheeled vehicles of Western European and American origin, such as the Mercedes-Benz G 270 CDI, Toyota Land Cruiser, the Cougar, the HMMWV (High Mobility Multipurpose Wheeled Vehi- cle), M1151A1 and the MaxxPro MRAP ( Mine resistant Ambush Protected ). In addition to this, the Hungarian Provincial Reconstruction Team (PRT) in Afghanistan received 7 pieces of Hungarian-made armored H14 RÁBAs with increased protection.

According to the security predictions projected to 2030, a conventional armed force at- tack against Hungary is not likely. However, Hungary is located in the buffer zones of coun- tries of different cultures, languages and religions and undertakes foreign military missions. Therefore, the armed forces of the Hungarian Defense Forces may be needed — in the home environment, or in mission areas — in traditional and non-war military operations alike. As a result of the more frequent and unpredictable weather the disaster management tasks — in the absence of others — require special offroad vehicles in the Army. So the army should be characterized by flexibility, multitasking and it should be installed easily. [6]

The armored combat vehicle fleet of the Hungarian Defense Forces mainly involves wheeled devices these days, among which the modern types can be found. However, the number of the types originating from many different manufacturers is low, which can cause maintenance difficulties. The number of tracked devices is small and they are obsolete. For further development of this field the outcome of the issue of "wheeled or tracked" is deter- mining. [1] 


\section{The role of mobility in the armed forces}

One of the distinguishing features of military science is the importance of mobility. The need for freedom of movement in the 20th century wars called for increased mechanization. It re- quires a sufficient number of good off-road capabilities and advanced machinery stock. The future's operations may be characterized and may contribute to "full-spectrum superiority" precision commanding, the full dimension protection and logistical capabilities in addition to the dominance of the maneuver. The actual tactical, operational and strategic significance of mobility is the reason that in the twentieth century mechanization of armies has so far grown explosively. [7]

Strategic mobility means the ground, naval and air transportability of military vehicles, tactical mobility means the locomotor ability of the vehicle in the terrain. The mobility of technical insurance is determined by the quality and timing of spare parts supply, the stan- dardized measure of structure and operation of materials, the repairability, service interoper- ability between field conditions. Mobility has a lot of components resulting from the above, thus ways of increase may be quite varied and complex. [8]

The tracked and wheeled military combat vehicles of good off-road ability are suitable for controlling land and water obstacles, in any climate and terrain conditions. In addition, they ensure the performance of equipment, they provide increased protection for the operating personnel and the cargo against the various devastating battle factors. The off-road vehicles should be able to act off-road, in the support of combat troops, to solve tasks of transport, supply and security in the field of combat material, supply food, delivery of maintenance materials, supply health insurance and logistics. The off-road vehicle is to overcome any obstacles where continuous and combined movement of groups of people is still possible.

In the terrain the proper mobility of wheeled vehicles is achieved mainly by the provision of all-wheel drive. The allwheel drive allows the vehicle to effectively perform military transport duties in war conditions on needed roads, in difficult terrain and in bad weather conditions. [8]

Today, in all modern armies of the world, land troops have different armaments and ad- ditional units of special teams. Separately examining the place and importance of these it is commonly accepted that the main role is played by mechanized infantry and tank troops, which are the most suitable for a fight in the circumstances of both conventional and mass destruction weapons. It should be noted, that the hostilities of the past decades does not verify definetly this statement. Tank troops are able to provide combat activity of high level and independence, the coup, the offensive combat and operational activities, a high degree of dynamism of adversity momentum, strength, depth, security conditions and a high level of endurance, flexibility and strength of the defense. Tank troops with these abilities provide an explanation to the fact that tank technology occupies a prominent place in military equipment development these days. [7] From the experience of wars, military activities, peace support, peace keeping and enforcement these days, military experts have no doubt that tanks are needed in order to fight battles. The main issue is not the quantity but the quality. The mod- ern tank really fills its role, if the planned and executed content embodies the most modern achievements. Therefore, reducing the number of models, the concept of development and production, the economy, efficiency and quality improvement will be highlighted. [9] It is 
very likely that in the first half of the next century that tanks will still retain an important role in the waging of war. It is also true that the development of anti-tank devices, the use of mines against tanks further increases expected battle losses, but — with armor protec- tion against a variety of targets and from the exchange opportunities effective fire opening through to a high degree of mobility — it remains indisputable: the tank remains one of the principal players of land battles. [10]

\section{The development of the theory of cross country mobility and tracked cross country mobility}

The main issues of the theory of military off road mobility already occurred in the $18^{\text {th }}$ centu- ry and the traction resistance was defined in the $19^{\text {th }}$ century. Between 1900 and 1910 instru- ments were made to measure features of soil, then, in the 1920s motility studies were con- ducted in sandy soil. Before World War II uneven road surface was measured by instruments and effects were evaluated and the relationship of tank and soil was tested. In the 1950s mathematical description of certain field effects (motion on loose ground, crossing obstacles) and mechanical analysis were carried out. In 1961 the international organization of terrain walking sciences was formed (International Society for Terrain-Vehicle Systems, ISTVS). The related technical achievements such as the design of the lunar rover contributed to the rapid development of this field of science. In the 1960s motility models were developed in the United States regarding the complexity of the issues, that is technical characteristics needed to evaluate terrain walking were summed up. The use of terrain models helped the planning and resulted in economic savings and helped the assessment of the expected results in tactical exercises. In 1971, the first generation of computer motility models (AMC-71) was created. [11] In Hungary in the field of testing off-road vehicles first place goes to Antal Nowody (M.Sc. mechanical engineer), who published the study series called Wormdrawing (A hernyóvontatás) [18] in 1925 in the journal of Müszaki Szemle. After World War II, in the studies of Kovácsházy Ernő ${ }^{2}$ — the tank constructor of the former Weiss Manfred factory

— and Clementis Gyula ${ }^{3}$, written for the postgraduate engineering and military engineering students of the Technical University of Budapest (Budapesti Müszaki Egyetem - BME), the structural characteristics and the use of tracked and wheeled vehicles are sharply differenti- ated. In 1981, the staff of the Military Technical Institute (Haditechnikai Intézet - HTI) pre- pared a summary on the technical characteristics of the evaluation of terrain walking in the article Technical Study of the Terrain Walking of Military Vehicles (number 81-9090) [19], and presented motility models and studies on kinetic models of NATO experimental insti- tutes. In the 1980s attempts were made to establish a domestic mathematical model for cross country mobility. The environment and vehicle characterizing matrices were created. The modeling of time - measuring instruments and demands exceeded the options, and finally the tests were terminated by the Military Technical Institute. HTI compared 25 types of ar- mored fighting vehicles in the March of 1987 with special regard for the connection between

2 Lánctalpas járművek hajtóműve, 1951. (Engines of Tracked Vehicles), A gépjármütervezés és méretezés elvei, 1952. (The Principles of Vehicles Design and Scaling), Lánctalpas és kerekes terepjáró gépjármüvek tervezése, 1952. (Design of Tracked and Wheeled Off-Road Vehicles)

3 A terepjárás elméleti és gyakorlati vonatkozásai, 1953. (The Theoretical and Practical Implications of cross road mobility, 1953), Lánctalpas járművek vonóerő kérdései, 1955. (Traction Issues of Tracked Vehicles) 
motility and protection and survivability. In the 1980s a cooperation emerged between HTI and the University of Agricultural Sciences in Gödöllö (Gödöllői Agrártudományi Egyetem — GATE) in the field of cross country mobility. About the results Lajos Laib provided infor- mation in the articleThe cross-country running of military vehicles, Determination of mo- tility model accuracy (Katonaijármüvek terepjárása, Mozgékonysági modellpontosságának meghatározása). [20], [11] Later history and soil mechanical and vehicle dynamical theory of cross country mobility was overviewed in his book Cross country moving vehicles (Terepen mozgó jármüvek). [21]. $\mathrm{h}$ the international literature 6 cross country driving J. Y. Wong (Theory of Ground Vehicles). [22] and M. G. Bekker (Theory of Land Locomotion: the me-chanics of vehicle mobility) [23] are worth mentioning.

\section{Wheeled or tracked device?}

Examining the mechanized formation of the world's armies, it can be conluded that there is no significant military force which is equipped with either wheeled or tracked equipments alone. In the neighbouring armies both types of devices can be found in large numbers, although in different proportions. The responsibilities of wheeled or armored off-road vehi- cles with track chassis are significantly different. Because of the different tasks the Defense Forces cannot be equipped with only tracked or wheeled off-road vehicles. The question is to be approached from the direction what proportion is required in the operation of wheeled or tracked vehicles, that is when and for what tasks are wheeled or tracked vehicles needed. So the question above should be changed to "when is wheeled and when is tracked chassis needed".

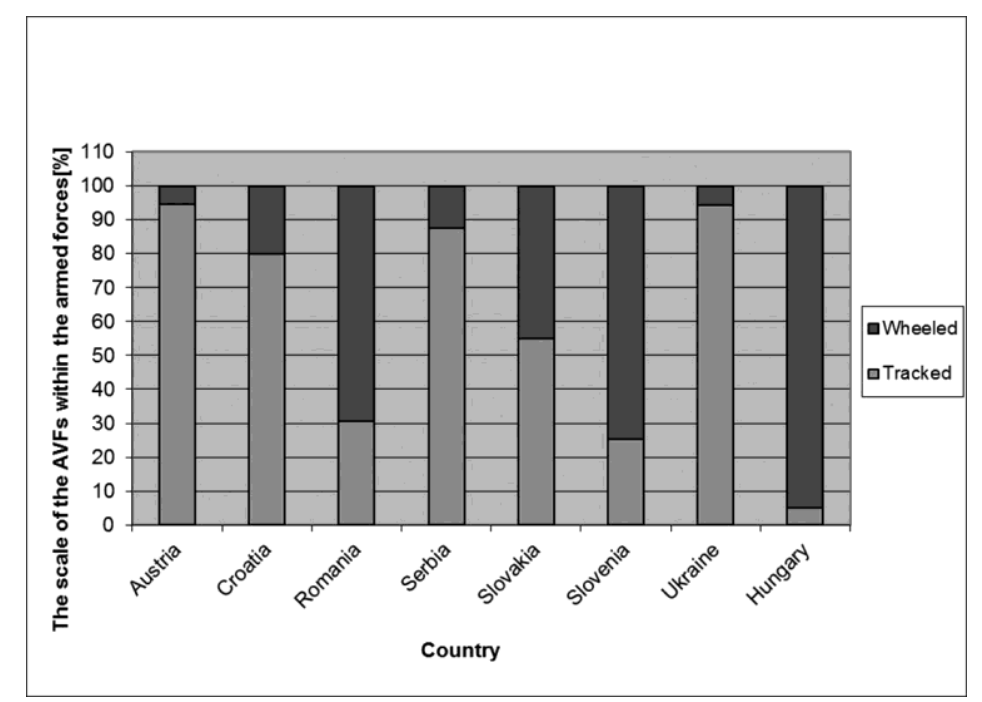

Figure 1. Distribution of wheeled and tracked combat vehicles in Hungary and the neighbouring countries within the armed forces [4] [17] 

Engineering Ltd. for the plans of RDO-3221 ABV Komondor "Development of NBV Re- connaissance Vehicle Provided with Terrain, Modular, Ballistic Protection”. This was the de- sign of a Hungarian produced armored off-road vehicle. This is a so-called MRAP vehicle, protected against IED (Improvised Explosive Devices) widely used in assymetric warfare. Komondor is organized according to MRAP ideas and has a V-shaped bottom, which can divert the blast of a possible explosion aside. It should be noted, that the Hungarian Defence Forces has not done — yet — any military tests (for examlpe ballistic defense) on it.
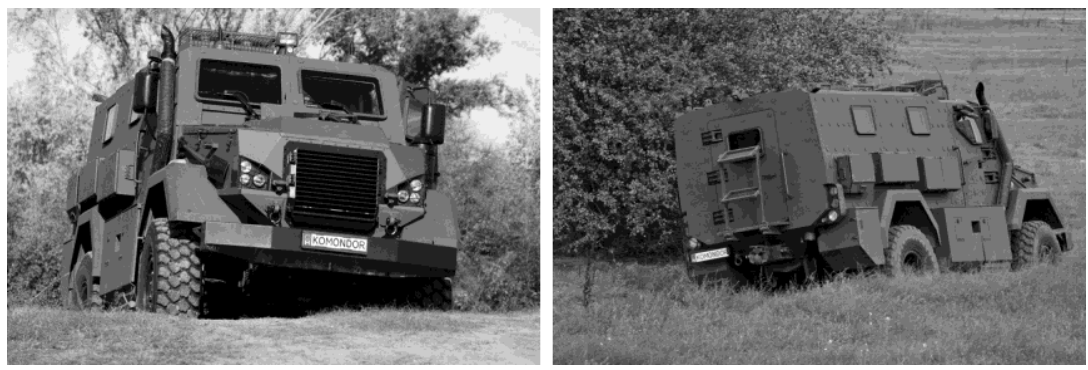

Picture 1. RDO-3221 ABV KOMONDOR [13]

The project is suitable for other purposes apart from the prototype (nuclear, bio, chem- ical, locator) like armored troop carrier, command vehicle, armored rescue vehicle or even self-propelled (off-road) chassis. It can be stated that the Hungarian-designed and produced device carries the following benefits:

- includes additonal national mental and physical value;

- generates a Hungarian supplier circle;

- new workplaces are created;

- a Hungarian engineering/industrial standard is created;

- Hungarian engineering activity is extended;

- Hungarian professional requirements can be met flexiblly, even in small series or in case of an individual item, or foreign interests can be attracted.

- and disadvantages:

(because of the degradation of Hungarian light- and heavy industry after the 80's)

- roundabout, full of pitfalls for development;

- certain raw materials, components, or parts purchasing needed from foreign import, dependence on foreign suppliers.

Of course, there are a number of possibles system MATERIALS and foreign-made equip- ment with the following disadvantages.

Naturally there are a number of options to purchase foreign-made, related devices, which have "comfortable" supply, but then again it results in the following disadvantages:

- it does not specifically tend to support the development of national industry;

- expectedly, it will hardly have additional national mental and physical value;

- it is surrounded by very strong information defence which makes it impossible to ex- ecute changes satisfying Hungarian needs and makes the maintenance and repair slow and difficult, even impossible in certain cases; 
- it is disadvantageous to take them to the logistic system since it is not guaranteed that the manufacturing process would create the technical service skills at the same time;

- a significant part of the repair material — in case of resupply — would only be deliv- ered for Hungarian demands which would increase the costs;

- finally (generally regarding the interests of all member nations in the case of industrial activities) in the period of peace and war the manufacturers' capacity cannot be mobi- lized in favour of the Hungarian State and Hungarian Armed Forces.

The raison d'etre of partially Hungarian made combat vehicles is supported by inter- national examples regarding the provision of national defense tasks. A number of nations attempt to rely primarily on their own industry within the framework of their alliance ob- ligations. Additional benefits would be caused if the significant additional part of defense expenses could be spent in the Hungarian manufacturing and service industry, therefore they would return to the Hungarian state budget. The Hungarian (military) industry still has the capability required for development and production, long- term maintenance and later mod- ernization of a vehicle fleet. [14]

\section{Comparison and selection of military equipment}

Methods commonly used so far for selection of military equipment — which were based on the examination of tactical and technical parameters and so-called professional experience

— need to change with new methods. Qualification, comparative analysis and the examina-

tion of technical standards with scientific methods should be focused on. [3]

Gyarmati József described it in his study Comparison of Military Equipment (Haditech- nikai eszközök összehasonlitása) [16] that acquisition and comparison of weapons and weap- on-systems is also a Multi-Criteria problem, in which methods of decision making theory, matching and ranking methods based on experts included in the field of economics need to be used. However, in the process of comparison it is not the question that out of two military devices which one is the better, but which of the two is more suitable to fulfill the intended task. The intended use for the battle circuit devices are not necessarily known since it cannot be estimated exactly in advance in what kind of combat situation, in what geographical con- ditions and which enemy combat devices they will fight. A military device will be applied op- posing other enemy devices following its nature, consequently, information is needed about the parameters and capabilities of the enemy assets. The Multi-Criteria making model ranks according to test criteria. Evaluation according to criteria and summary of the obtained val- ues can be done in several ways on the basis of MultiCriteria, making theory methods such as AHP [15], PROMETHEE and SMART procedures. [16] A military device is used for a significant period — even decades — and its costs of acquisition are also high, so the respon- sibility of people preparing and making the decisions is very high. In certain situations when adequate numbers of competent experts and data necessary for the previous methods are not available — such as comparing tanks — matching may lead to incorrect results. Several mil- itary off-road vehicles are offered by military industry worldwide. Hungary and the Hungar- ian Defense Forces cannot purchase all the available and suitable types, so their comparison on the test track cannot be carried out. Various vendors do not provide detailed information and measurement results for their products. These technical devices are results of military industry research including technical solutions developed by long and expensive procedures 
in order to protect "know-how" and to increase their own military potential. Opinions can only be formed through the limited catalogue data or the physical appearance, even in the case of serious requests. In addition there are very few experienced armored vehicle officers

- who have been to war — whose opinion could be relied on in the tests to correctly select and match an off-road device adequate for our purposes. Though it is not necessary to know all the details of the research and development, and it is not necessary either to have a large number of experienced experts if another method is used.

In this case it can be more appropriate to rank on the basis of "tangible" and expansive technical data, in the book Heavy tanks (Nehéz harckocsik) by Turcsányi Károly [24] the comparison of World War II tanks was carried out by the method and complex system of KESSELRING's. The applicability of the method for armored devices was proved by setting up a sequence generation rank-correct according to other approaches. Possessing an ade- quate knowledge of vehicle dynamics, terrain mechanics and users' needs and requirements collecting the aspects defining cross country mobility and considering the designated area of use, the required device can be selected by the adequate comparison method with a good approximation through little but informative data.

\section{Summary}

It can be stated on the basis of directives and objectives determined by Hungarian military strategy that the Hungarian Defense Forces will need armored off-road vehicles in the future. The Hungarian Army should be equipped with a sufficient number of tracked and wheeled off-road vehicles in accordance with national and international duties and commitments. It is to decide that the deployment of new devices can be carried out by modernizing a part of the existing vehicles and/or by purchasing new devices in a satisfactory way. It is also to examine the possibility of the wider involvement in connection with this activity requiring large finan- cial resources. The application of suitable methods of decision making theory can succeed in fast and accurate results in selection and matching combat vehicles for the same role.

\section{References}

[1] KUNOS B.: A haderőreform haditechnikai aspektusai. Hadtudomány, X 3 (2000) www.zmne.hu/kulso/mhtt/hadtudomany/2000/3_3.html (downloaded: 2201 2014)

[2] KÁLMÁNFI G.: Újra kell építenünk a magyar hadiipart. Honvedelem.hu www.honvedelem.hu/cikk/31735/\%E2\%80\%9Eujra-kell-epitenunk-a-magyar- hadiipart\%E2\%80\%9D (downloaded: 22012014 )

[3] KUNOS B., TURCSÁNYI K., TÓTH B. (1997): A Magyar Honvédség haditechnikai korszerúsítésének elvei, lehetőségei és követelményei. In. Tanulmánygyüjtemény. Válogatás a Honvédelmi Minisztérium 1996. évi kutatási eredményeit összegezö tanulmányokból. Budapest: Honvédelmi Minisztérium Oktatási és Tudományszervező Osztály, pp. 188-205.

[4] FOSS, C. F. (2009): Jane's Armour and Artillery 2009-2010. London: Jane's Information Group

[5] www.hkho.eoldal.hu/cikkek/mh-szarazfoldi-eroi-fegyverzete.html (downloaded: 2401 2014) 
KOVÁCSHÁZY Miklós: The Modernization of the Armored Combat Vehicle Fleet...

[6] BODORÓCZKI J.: A Magyar Honvédség a XXI. században (Gondolatok az új kihívásokról). Hadtudományi Szemle, 62 (2013), 1-9. www.uni-nke.hu/downloads/ kutatas/folyoiratok/hadtudomanyi_szemle/szamok/2013/2013_2/2013_2_hm_bodoroczki_janos_1_9.pdf (downloaded: 2201 2014)

[7] TURCSÁNYI K.: A harckocsik modernizálásának lehetőségei. Honvédelem, XXXVII 8 (1986), 58-64.

[8] TURCSÁNYI K.: Hazai gyártású katonai terepjáró gépjárművek a Magyar Honvédségnél. Hadtudomány, VII 1 (1997), 113-118.

[9] TURCSÁNYI K.: A harckocsik alkalmazásának fejlődése megjelenésétől napjainkig. Katonai logisztika, 74 (2000), 174-175

[10] CZOLLER E. (1997): Korszerủ szárazföldi haderő az ezredforduló után. In. Tanulmánygyüjtemény. Válogatás a Honvédelmi Minisztérium 1996. évi kutatási eredményeit összegezö tanulmányokból. Budapest: Honvédelmi Minisztérium Oktatási és Tudományszervező Osztály, pp. 206-218.

[11] VÖLGYI K. (2005): Katonai gépjármúvek terepjárásának elméleti kutatása és oktatása. In. Varga A. J. (Ed.): A magyar harc-és gépjármüfejlesztések története. pp. 403-410.

[12] www.gammatech.hu/?module=news\&newsid=7\&lang=hun (downloaded: 2101 2014) [13]

www.totalcar.hu/tesztek/2012/11/07/rdo-3211_komondor_meg_kell_oljelek/2/ (downloaded: 2101 2014)

[14] www.respirator.hu/komondor/ (downloaded: 2101 2014)

[15] GYARMATI J.: Haditechnikai eszközök összehasonlítása közbeszerzési eljárás során. Katonai logisztika, 12 (2004), 68-93.

[16] GYARMATI J. (2008): Haditechnikai eszközök összehasonlitása (útmutató). Budapest: Zrínyi Miklós Nemzetvédelmi Egyetem, Katonai Logisztika tanszék

[17] STEFANCSIK F.: Haderökörkép Európából. Új Honvédségi Szemle, LIX 11 (2005) 76-82. [18] NOWODY A.: A hernyóvontatás. Müszaki Szemle I. és II. (1925. január-december, 1926. január-december), Budapest: A Kir. József Mủegyetemhez csatolt Technikai Kísérleti Intézet kiadványa

[19] HADITECHNIKAI INTÉZET (1981): Müszaki tanulmány a katonai gépjármüvek terepjárásárólm témaszám: 81-9090. Budapest: Haditechnikai Intézet

[20] LAIB L. (1985): Katonai járművek terepjárása, Mozgékonysági modell pontosságának meghatározása. Haditechnika, XIX 3 (1985), 2-9.

[21] LAIB L. (2002): Terepen mozgó jármüvek. Budapest: Szaktudás Kiadó Ház Rt. [22] WONG J. Y. (2008): Theory of Ground Vehicles. John Wiley \& Sons

[23] BEKKER M. G. (1962): Theory of Land Locomotion: the mechanics of vehicle mobility. University of Mitchigan Press

[24] TURCSÁNYI K. (2009): Nehéz Harckocsik, Összehasonlitó értékelések, müveleti alkalmazások és a magyar TAS tervezése. Budapest: Puedlo Kiadó 